\title{
The Relationship between Work Period and Dust Level with Disruption of Lung Capacity in Asphalt Mixing Plant Production Workers (AMP) Medan in Public Works Office 2019
}

\author{
Dinda Sekar Mentari ${ }^{1}$, Taufik Ashar ${ }^{2}$, Nurmaini $^{3}$ \\ 1,2,3 Department of Environmental Health, School of Public Health, University of North Sumatra, \\ Indonesia \\ Email: dindasekarmentari@yahoo.com
}

\begin{abstract}
:
One of the most potent sources of air pollution is from the industrial sector. The air pollutants produced from the industry are TSP dust. Long exposure for a long time can pose a risk in the form of impaired pulmonary function capacity. The purpose of this study was to find out the relationship between years of work, dust levels with impaired lung capacity in the environment of hot mix asphalt production officers in the Public Works Office of Medan City. This type of research is observational analytic with a cross-sectional design. A sample of 45 workers in the hot mix asphalt production section in the AMP area of the Medan City Public Works Service. The results of the study found that the dust levels in AMP were still below the NAB, ranging from 2-8.10 $\mathrm{mg} / \mathrm{m3}$, workers who had pulmonary function disorders were 15 people (34\%). The results of the analysis using the Pearson correlation test showed that there was a moderate relationship between dust exposure and lung function capacity with a value of $r=-0.432, p=0.003$, and there was a weak relationship between the work period and the function of pulmonary function with a value of $r=-$ $0.384, p=0.009$. Therefore, it is recommended to the Public Works Office of Medan City to provide respirators for workers to prevent the excessive entry of dust into the body.

Keywords:

work period; exposure to dust; lung capacity
\end{abstract}

\section{Introduction}

Air is a mixture of gas found in the layer that surrounds the earth. In urban and industrial areas, many operate various factories such as chemicals, cement, plywood, and others. Industrial activities have the potential to produce air pollution materials. Air pollutants that can be released by industry are dust particles, SO2 gas (sulfur dioxide), NO2 gas (nitrogen dioxide), CO gas (carbon monoxide), NH3 gas (ammonia), and HC (hydrocarbon) gas (Mukono, 2008).

AMP (paved mixed production unit) is an industrial sector that has a set of mechanical and electronic equipment in which aggregates are heated, dried and mixed with asphalt to produce hot asphalt mixtures that meet specific requirements and potentially emit air pollution. AMP can be located in a permanent location or move from one place to another. The manufacturing process itself consists of three stages, namely from preparation, stone abuse, mixing of asphalt, and aggregate using AMP. Machine, which creates the potential to remove dust and disrupt lung function capacity.

Data from the ILO (International Labor Organization) in 2010 can be concluded that there are $10-30 \%$ of occupational diseases in the form of lung disease, with the number of new cases of 40,000 pneumoconioses every year. The PPM and PL directorate-general in Indonesia say the highest morbidity rate is in obstructive pulmonary disease by $35 \%$, bronchial $33 \%$ and lung cancer $30 \%$. 
A worker who works eight hours a day will install A worker who works 8 hours a day will install about $10 \mathrm{~m} 3$ of breathing air, or more or less the same as what people need in a state of rest per day. Old contacts with an environment containing dust particles will cause stress disorders in the respiratory tract organs, making it easy to cause various types of lung diseases (Harrianto, 2010). Workers who are exposed to dust levels for an extended period with a minimum of 5 years working period cause pneumoconiosis, this is characterized by symptoms such as coughing and shortness of breath due to the massive accumulation of dust in the lungs. Based on Regulation of the Ministry of the Labor Republic of Indonesia number 05 of 2018 concerning occupational safety and health in the work environment, which includes the threshold value of physical and chemical factors in the work environment, namely inhalable particulate dust limits which are permitted to enter the human body at $10 \mathrm{mg} / \mathrm{m} 3$. The benefit of this research is to provide information to officers in AMP Medan City about the effects of the level of dust on health. Provide input to agencies on the effects of air pollution, especially dust, to prevent health problems.

\section{Research Methods}

This study uses the analytic method with a cross-sectional design. The dependent variable of this study is pulmonary function disorder. While the independent variables are dust exposure, work period and length of work which aims to determine the relationship between exposure to dust and work period with pulmonary dysfunction in workers of asphalt production in the Medan Public Works Agency in June 2019.

The population of this research is all workers at AMP Medan Public Works Agency, especially in the production unit. The sampling technique in this study uses a total sampling technique, where the determination of the sample is by taking the entire population with the consideration that the study population is quite small. The population of workers is 45 person.

\section{Result and Discussion}

Univariate analysis in this study to see the frequency distribution of the characteristics of respondents, the characteristics of respondents consisted of age, years of service, smoking habits, use of Personal Protective Equipment (PPE) and Body Mass Index BMI.

Table 1. Distribution of Frequency Characteristics of Respondents

\begin{tabular}{lcc}
\hline Characteristic & $\mathbf{n}$ & $\mathbf{\%}$ \\
\hline Age & & \\
$\quad<30$ years & 11 & 24 \\
$\quad>30$ years & 34 & 76 \\
Work Period & & \\
$\quad<5$ years & 3 & 7 \\
$\quad>5$ years & 42 & 93 \\
Smoke & & \\
$\quad$ Yes & 22 & 49 \\
$\quad$ No & 23 & 51 \\
The use PPE & & \\
$\quad$ Yes & 20 & 44 \\
$\quad$ No & 25 & 56 \\
BMI & & \\
$\quad$ Thin and Fat & 25 & 56 \\
$\quad$ Normal & 20 & 44 \\
\hline
\end{tabular}


Based on table 1, the result showed worker dominant $>30$ years $(76 \%)$ as many as 34 people, production workers bitumen has a mass of work most of $>5$ years as many as 42 people $(93 \%)$. Based on the variable smoke there are as many as 22 people $(49 \%)$ have smoking habits. Meanwhile, the use of PPE, especially masks, shows that as many as 20 people (44\%) use PPE in the form of masks while working. For the BMI variable, there were 25 people $(56 \%)$ who had abnormal BMI values (thin or fat) while for normal BMI values, there were 20 people (44\%).

Based on the examination of workers' lung capacity by using a spirometer type HI-801 are categorized into standard and no interference. In an examination using a spirometer found no interference in the form of restrictive, obstructive, and mixed. These results are presented in the following table:

Table 2. The distribution is based on the capacity of the lung function

\begin{tabular}{lcc}
\hline Lung capacity & $\mathbf{n}$ & $\mathbf{\%}$ \\
\hline Abnormal & 15 & 34 \\
Normal & 30 & 66 \\
\hline Total & 45 & 100 \\
\hline
\end{tabular}

The table 2 shows there are 15 people (34\%) who experience impaired lung function and 30 people $(66 \%)$ people who do not experience lung capacity disorders.

Table 3. The Relationship between Dust Exposure and Work Period with Lung Function

\begin{tabular}{lcc}
\multicolumn{3}{c}{ Capacity } \\
\hline Lung capacity & $\mathbf{p}$ & $\mathbf{r}$ \\
\hline Dust & 0,003 & -0.432 \\
Work Period & 0.009 & -0.384 \\
\hline
\end{tabular}

Based on Pearson's correlation results, we can see variables of dust and work period. There is a relationship with the value of $\mathrm{p}=0.003$ with $\mathrm{r}=-0.432$ meaning having a strong relationship with the opposite direction, while work mass had a weak relationship with lung capacity with a value of $\mathrm{p}=0.173$ and $\mathrm{r}=-0.384$

\subsection{The Relationship between Dust Exposure and Lung Function}

The results showed that there was a relationship between dust levels and lung capacity (FVC) with correlation values $(\mathrm{r}=-0.432), \mathrm{p}=0.003$, and negative. Dust comes from the asphalt manufacturing process, which consists of the stages of preparation, processing, and transportation of the results. The results of dust measurements from four sampling points did not find dust levels exceeding $\mathrm{NAB}>10 \mathrm{mg} / \mathrm{m} 3$ based on RI Minister of Manpower Regulation No.05 of 2018 concerning occupational safety and health in the work environment. The highest dust content is found in the asphalt production site, which is $8.10 \mathrm{mg} / \mathrm{m} 3$ while the lowest dust content is in a location that has a distance of about $500 \mathrm{~m}$ from the place of the asphalt production machine. Although the level of dust is below the NAB, it can affect the respiratory system.

According to the results by Yusri (2012) in Aceh, the asphalt production industry has a level of dust that does not meet the requirements. High dust levels significantly affect the productivity and health of asphalt production officers. Old contacts with a work environment that contains dust particles will cause stress disorders in the respiratory tract organs, making it easy to cause various types of lung diseases and other respiratory diseases such as restrictive, obstructive or combination. Lung disease is determined by the organs where particles are stored, 
duration and dosage exposure, susceptibility of lung cells due to the toxic effects of dust particles, and the special effects of interactions between toxic particles and individual lung defense mechanisms (Suma'mur, 2013 )Declining capacity particularly restrictive lung function occurs because of blockage in the respiratory tract. From the interview to the official production of asphalt in Asphalt Mixing Plant (AMP) in Public Works Department of Medan when the study of people with impaired lung function restrictive have such complaints often feel short of breath when working, often have a persistent cough and often feel chest pain. This is in line with Khumaidah (2009), exposure to long and frequent respiratory complaints can cause high against the risks of obstructive lung disease.

\subsection{The Relationship Between Work Period with Lung Function Capacity}

Based on the results, there was a weak correlation between working period with lung function capacity with the value of the correlation coefficient person's $(r=-0.384)$ were weak or negative; it means having the opposite direction. The working period referred to in this research is the length of time workers are employed at the production of asphalt from the beginning of the work until the time of the study. In this study, respondents were most impaired lung function of workers who have worked $>5$ years. The longer service life of a person in the year, the lower lung function capacity value of $<80 \%$ so that it has the form of a restrictive effect.

The working period determines how often and for a long time, a worker exposed to the dust. These variables associated with variable levels of dust, because the longer the exposure obtained, the higher the potential for the accumulation of dust in the respiratory tract and cause pulmonary function impairment.

The results are consistent with the theory Sumamur (2009), a person who worked $>5$ years have a significant risk of impaired lung function compared to those who work $<5$ years. The longer service life of a person with a working environment full of dust and polluting it would be more easily someone decreased lung function.

\section{Conclusion}

The results showed that there is a relationship between work period with lung function capacity disorders $(p=0.009)$, and there is a relationship between exposure of dust and lung function capacity $(\mathrm{p}=0.003)$ in asphalt production workers at the Public Works Agency of Medan.

Based on these results, it is hoped that the Public Works Office of Medan will make a proper working system regulation to minimize dust drifting in the air from the work environment inhaled by workers. It is expected that the distribution of PPE for office workers can be distributed regularly and evenly and so that workers can use PPE properly.

\section{References}

Candra B. 2005. Introduction to Environmental Health Jakarta: EGC.

Fardiaz, S.2010. Water and Air Pollution. Yogyakarta: Kanisius.

Guyton, A., Hall, JE1997. Textbook of Medical Physiology Physiology 9th Edition. Jakarta

Grandjean, E., 1993, Fitting the Task to the Man, 4th ed, Taylor \& Francis Inc., London.

Khumaidah. 2009. Analysis of factors associated with impaired lung function in workers of PT.

Teak Furniture Village Suwawal Furnindo City Subdistrict Jepara regency Mlonggo

Diponegoro University. Semarang. 
Mukono. 2000. 2. Basic Principles of Environmental Health Airlangga University Press. Surabaya.

Mukono. 2005. Environmental Toksokologi. Airlangga University Press. Surabaya

Mukono.2008.Pencemaran Air and Its Effect on gangguan.Airlangga University Press. Surabaya.

Prima. H. 2010. The concentration of Asphalt (Hotmix). Jakarta.

Sarjani, Rizki.2015. Analysis of Air Quality and Respiratory Health Complaint and Grievance Eye Irritation Workers in Pertenakan Cows On PT.PRIMA Indo Mandiri Sejahtera Berastagi Year 2013. Faculty of Public Health Universitas Sumatera Utara. Field.

Simaela, S. (2000). Factors Associated with Lung Capacity Maximum of Stone Crusher Company Workers at PT. P in Bogor. Thesis. Universitas Indonesia. Jakarta

Sugiyono. (2010). Quantitative Research Qualitative and RND. Bandung: Alfabeta Soemirat, J. 2009. Environment Health. Gadjah Mada University Press, Yogyakarta.

Sukirman.S. 2003 Hot Mix Asphalt. Granite, Jakarta Press.

Suma'mur, PK, 2013. The Company Hygiene and Health at Work. Gunung Agung, Jakarta.

Yusri. 2012. Influence of Environment on Asphalt Production Activities Hotmix the Syndrome of Acute Respiratory Infections (ARI) on workers and citizens in the Region Port Balohan Sabang in Sumatra 2011.Universitas Utara.Medan

Mikki N. Anaemia prevalence and associated sociodemographic and dietary factors among Palestinian adolescents in the West Bank.

Ministry of Health Republic of Indonesia, 2013 Jakarta Basic Health Research Agency for Health Research and Development Ministry of Health of the Republic of Indonesia.

World Health Organization 2014, Global nutrition targets 2025: anaemia policy brief, WHO, Geneva

World Health Organization 2015, The Global Prevalence of Anemia in 2011, WHO, Geneva. 